\title{
Digital Public Administration: Possible Risks and Opportunities
}

\author{
Kipervar E. ${ }^{1, *}$ Mamay E. ${ }^{2}$ Kipervar E. ${ }^{2}$ \\ ${ }^{1}$ Omsk State University, Omsk, 644077, Russia \\ ${ }^{2}$ Omsk State Technical University, Omsk, 644050, Russia \\ *Corresponding author.Email: kea2025@gmail.com
}

\begin{abstract}
The article deals with theoretical aspects and the role of digital technologies in the process's transformation of social and economic systems management in modern conditions. The urgency of the article is determined by the rapid pace of the digital technology's development and their active penetration into all spheres of human and social activity. The aim of the study is to determine the risks and possible benefits in view of changes in the processes of socio-economic systems management that occur during the active use of digital technology. Defined the following objectives of the study: to specify the concepts associated with the functioning of the state in a digital format, changing the processes of socio-economic systems management under the influence of digital technologies, the degree of interest of citizens and business in the processes of digitalization of public services, analysis of risks and opportunities of digital government. As a result of the study the concept of digital economy was refined, changes in the processes of social and economic systems management under the influence of digital technologies were considered, satisfaction and the degree of use of digital technologies were analyzed, risks and opportunities of digital public administration were identified.
\end{abstract}

Keywords: socio-economic system, digital economy, digital technology, governance processes, digitalization, digital government, public services

\section{INTRODUCTION}

Rapid development of digital technologies and their active use leads to changes in all spheres of human activity. Digitalization provides an opportunity to obtain new knowledge and professions. Changes occurring in the processes of managing social and economic systems are large-scale. Implementation of projects on digitalization of public administration provides an opportunity to effectively manage data and information, improve the availability and quality of services to citizens and businesses, increase the competitiveness of enterprises and countries in the world.

\subsection{Our Contribution}

This paper presents approach to identify risks and possible benefits in view of changes in the management processes of socio-economic systems that take place during a period of active digital use. The tasks of the work include specification of concepts related to the functioning of the state in digital format, changes in the processes of socioeconomic systems management under the influence of digital technologies, the degree of interest of citizens and business in the processes of digitalization of public services, analysis of risks and opportunities of digital government.1.3. Paper Structure

The rest of the paper is organized as follows. Section 2 introduces the preliminaries used in this paper, which include PAs, model checking and the $\mathrm{NL}^{*}$ algorithm. Section 3 presents a compositional stochastic model checking framework based on the SYM rule and optimizes the learning framework. Then, the framework is extended to an $n$-component system $(n \geq 2)$ in Section 4 . Section 5 develops a prototype tool for the framework, and compares it with Feng et al. [23] by several large cases. Finally, Section 6 concludes the paper and presents direction for future research

\section{MAIN PART}

The transition to an innovative economy poses a challenge for Russia in overcoming the lag in development compared to the countries of world economic leaders. As a factor in solving this problem, it is necessary to form qualitatively new ways of managing social and economic systems that precisely and quickly respond to changes in the external and internal environment. The possibility of achieving the most important goals of Russia's socioeconomic development arises with the development and mastery of technologies. Of fundamental importance is the competent digitalization of public administration bodies. 
Let us consider the basic concepts and definitions of digital government and economic management.

In one report, the World Bank defines "digital economy" as a system of economic, social and cultural relations based on the use of digital information and communication technologies". [4].

The Organization for Economic Development and Cooperation (OECD) uses the term "digital economy" in relation to information and communication technologybased markets used to trade in information, digital goods or services via the Internet [9, 58-69].

The Strategy for the Development of the Information Society of the Russian Federation for 2017-2030 states: "The digital economy is an economic activity in which the key factor of production is data in digital form, the processing of large volumes and the use of the results of analysis of which, compared to traditional forms of economic activity, can significantly improve the efficiency of various types of production, technologies, equipment, storage, sale, delivery of goods and services" [9, 58-69]. [4].

Thus, analyzing the abovementioned terminology, we concretize the concept of "digital economy".

"Digital economy" is a system of social and economic relations, in which there is an active development of the economy, business processes, the system of social sphere management is transformed using modern information and communication technologies.

Digital economy is focused on creating the necessary conditions for the emergence of new breakthrough and promising digital technologies, and their application in business organization, trade, logistics and production. Digital technologies change the system of implementation of enterprises' strategy in everyday activities, increase the efficiency of investment and open new opportunities in the market. The active use of methods for analyzing large volumes of data creates the conditions for obtaining new knowledge and making effective management decisions. [9, 58-69].

At a meeting of the Council on Strategic Development and Priority Projects, Russian President Vladimir Putin said: "Digital technologies are not a separate industry, in fact, they are a way of life, a new basis for the development of public administration, economy, business, social sphere and the whole society. Formation of digital economy is a matter of national security and independence of Russia, competition of domestic companies".

According to the President, digitalization is a serious tool for solving social and economic problems. In particular, he notes that digital technologies simplify feedback from citizens, people become participants in solving problems, which allows them to respond to problems in a timely manner and make managerial decisions.

Vladimir Putin emphasized that "without digital economy, the country will not be able to move to the next technological mode, and without this transition, the Russian economy has no future" [8].

The goal of creating "Digital Government is to provide "citizens and organizations with access to priority public services and services in digital form, to create a national data management system, to form the infrastructure of egovernment, to introduce cross-cutting platform solutions in public administration" [11].

New technologies change the way people and organizations interact and organize their activities, create new products, and lead to qualitative changes in the socioeconomic sphere. Such changes in literature have been called "digital transformation" - revolutionary changes in society associated with the introduction of modern information technologies. Strategies of digital transformation are often aimed at changing products, processes, organization of activities, interaction and management and based on the application of innovative technologies. [18]

E.V. Kholodnaya understands e-government as a form of public administration implementation based on synergy between ICT and information resources (data) for the purpose of public service provision.

Special characteristics of the "new public administration" are referred to [18]:

- efforts to digitize interaction with citizens and organizations;

- the use of "one-click" technology that does not require human intervention;

- drastically reducing redundant processes in service delivery;

- establishment of the state on the principle of "do it yourself" based on the active involvement of citizens in the process of providing public services;

- the possibility to assess the efficiency and effectiveness of the provision of public services;

- establishment of incentives for bodies and organizations, responsible for provision of public services;

- client orientation and recording of "feedback".

As a matter of fact, it follows from all the above that, creating a "digital state", we create a national system of data management, new types of goods and services, there are qualitative changes in the socio-economic sphere. But we should not forget about all sorts of risks that arise in the transition to a "digital government". Are the risks that the state faces justified in building a "digital state"? To refute or confirm the hypothesis, it is necessary to consider how Russia is building a digital state.

In Russia, a lot of work is being done to develop and master basic, as well as the latest digital technologies in state administration. In order to develop electronic government, a set of federal laws has been adopted, based on which a public services portal has been created, transparency of the activities of public authorities has been ensured, and interdepartmental interaction based on the "one stop shop" principle is being actively developed. Their application is planned in the sphere of provision of public services, performance of control and supervisory functions, mastering of the management principle based on the results $[6,15-19]$. It is necessary to achieve that the changes occurring under the influence of digitalization will lead to an increase in the quality of public services, 
reduction of unjustified state interference, increase in efficiency and effectiveness of public administration.

As is known, a significant mass of our country's residents are quite traditional. For the most part, they are not inclined to learn new knowledge and skills. This is due to various reasons: age, character, financial status, etc. When introducing digital technologies into the system of state administration on a large scale, it is important to achieve a high level of public support for the policy of digitalization of the state apparatus.

The start of Russia's public administration system digitalization process took place in 2008, when the President of the Russian Federation issued the "Strategy of Development of the Information Society in the Russian Federation". To implement this strategy, the Information Society Program (2011-2020) was created. It is the first state program with a transition to program principles of the country's budget formation. The main direction of the program is the creation of an integral and effective system for the use of information technologies in all sectors and spheres of society. The aim of the programme is to provide citizens and organizations with the greatest benefit from the use of information technology and to create mobile interaction between the State and citizens and organizations [13, 22-36].

The programme contains the following provisions:

- development of e-government;

- improving the quality of public administration through the creation of

- and the introduction of modern information technologies;

- provision of services based on information technologies in medicine, health care and social security;

- development of services based on information technologies in the field of education, science and culture;

- support of regional projects in the field of information technologies.

Due to the implementation of this program, Russia has made progress in the creation of e-government, which was implemented in the provision of state and municipal services in electronic form. The development of multifunctional centres and the formation of a system of interdepartmental electronic interaction of basic state information resources have been initiated. Digital platforms were created - the Unified Portal of State and Municipal Services which in 2015 will be integrated with the Unified Identification and Authentication System.

At the time of launch of the public services portal in 2009, 110 federal and 200 municipal services were provided on it. In 2018, through the application, users completed and sent over 12.6 million electronic application forms for public services. In 2018, the portal registered 86 million people $-60 \%$ of the total Russian population. Figures 1.2 show the monitoring of the number of registered users of the public services portal and the number of public services provided in 2010-2018.

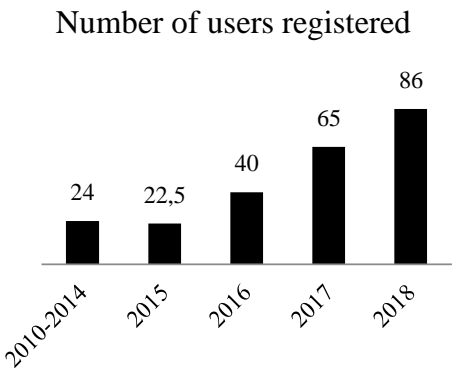

Figure 1 Number of registered users of the public services portal, million people

The number of users of the public services portal is increasing every year. In 2018 alone their number increased by 21 million, in 2017 by 25 million and amounted to 65 million. Total since 2012 the number of users of the portal has increased almost 20 times. Thus, in 20123.6 million citizens were registered at YSPU, in 2013 - 6.9 million, in 2014 - 13 million, in 2015 - 22.5 million, in 2016 - 40 million. The number of visits to the portal has increased by more than $30 \%$ and for 2018 is 582 million.

The number of services provided through the public services portal is growing rapidly. In total in 2018 through the portal users filled out and sent more than 60 million electronic forms of applications for public services, which is $55 \%$ more than in 2017. There is an active growth in satisfaction of citizens with the quality of public services [7, 123-125]. (Figure 2)

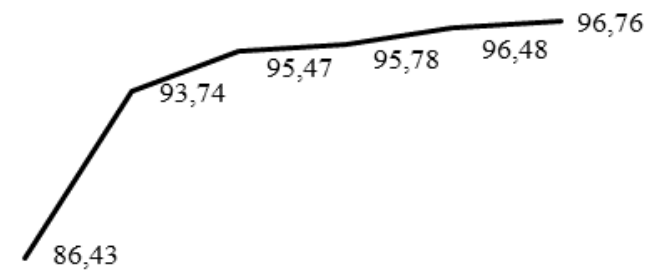

$$
\begin{array}{llllll}
2013 & 2014 & 2015 & 2016 & 2017 & 2018 \\
& &
\end{array}
$$

Figure 2 Statistics of public services assessment

The level of feedback from citizens is also increasing. According to the Information and analytical system for monitoring the quality of public services, the number of assessed public services for the period 2017-2018 increased by 1.8 times (Figure 3 ). There has also been an active growth in the number of left feedback on the provided public services, while in 2013 their number was 
1,100 per year, in 2018 it was 89.5 thousand feedback. This shows an active desire to involve citizens in governance processes [7, 123-125].

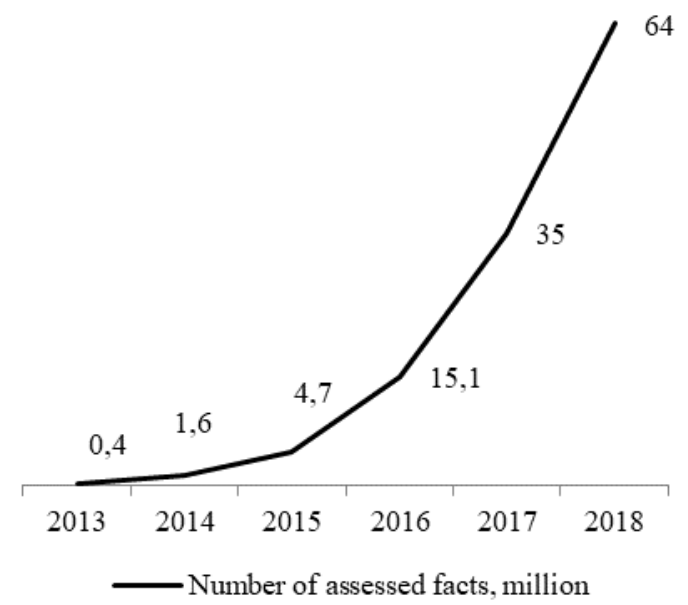

Figure 3 Number of assessments of public services

In 2017, the "Strategy for the Development of the Information Society of the Russian Federation for 20172030" was adopted. It identifies goals, objectives and measures to implement our country's policy in the field of information technologies application, which are aimed at formation and development of information society, national digital economy, and implementation of strategic national priorities [13, 22-36].

The programme highlights the basic principles and elements for the establishment of a digital government.

Principles: default digital service, platformependency and mobile orientation, user-oriented service design, digital services from start to finish, government as a platform Elements: single portal, common data for sharing in the public sector, interagency services for shared use public infrastructure for shared use, enhanced sensory networking and analytics, cybersecurity and confidentiality

Among the presented principles and elements, the key direction is the formation of the state as a "digital platform" aimed at uniting data, information and services into one digital portal. Due to the interest of the current management system in preserving its position, there are some difficulties in the development of the state in this direction [1].

The next step is to adopt a national program "Digital Economy of the Russian Federation". (2018-2024) [11]. The focus of this programme is "to improve the welfare and quality of life of citizens by increasing the availability and quality of goods and services created using modern digital technologies, increasing the degree of digital literacy, accessibility and quality of public services for citizens" [11]. [19 ]. The aim of the program is to create a systematic development and implementation of digital technologies in all areas of life. Digitalization of economy is a matter of global competitiveness and national security of the country. The goals and objectives of digital economy development are defined until 2024 within the framework of five basic directions: - normative regulation; - human resources and education; - formation of research competencies and technical reserves; - information infrastructure; - information security. Implementation of the program will contribute to the improvement of Russian legislation and business processes of commercial organizations, in electronic form (15) Seven out of 10 state services for business and citizens should be provided in digital form by 2024. Without personal visits to government agencies, all priority public services and services should be available. And $90 \%$ of the document flow between officials should be online.

The digital trends observed today cover almost all spheres of life: from medicine and education to taxi calling, are characterized by the "sterilization" of the economy and are carried out on special digital platforms.

Technology is providing more and more opportunities every year. The foundation of e-government: "Digital transactions are 50 times cheaper than live communication between two people, 20 times cheaper than telephone and 30 times cheaper than postal" (21).

There are 968 federal government services available on the portal. The most popular service is to provide information on the presence of tax and court debts, the status of personal accounts in the Pension Fund of Russia. Vehicle registration services, registration and enrollment of children in kindergartens, issuance of driving licenses, foreign passports and registration at the place of residence and stay are also popular. There has been an increase in payments made through the portal. A project to replace paper notices with electronic notices is being implemented, while maintaining legal significance.

During 2018, more than 16 million inquiries were made about the status of the personal account with the Pension Fund of Russia. Vehicle registration service was used 4.8 million times. About 3 million applications were received for last generation foreign passports and for registration of property rights. Almost 2.6 million services were provided to replace driving licenses. There were 10 million inquiries about court debts, 8.5 million about tax debts and 7.3 million traffic police fines.

Annually, the UN benchmark rating "E-Government Index" is calculated. It is a numerical value that reflects the degree of economic, social and democratic development of the country in question. The e-Government Index is an average of three main indicators: Internet availability (measured by website analysis), telecommunication infrastructure (measured by end-user IT equipment and its use on the Internet), and human capital (measured by the Human Development Index, Access to Information Index, and population density) [12].

In 2018, Russia is at 32 positions. In 2016, it was at 34 positions. The level of development is estimated as "very high" and is 0.7969 .

The introduction of new digital technologies, data sources, the use of advanced analytical methods carries both great potential and all kinds of risks (Figure 8). In a digital economy, a characteristic feature is the high intensity of radical changes, which undermine established social and economic relations. Undoubtedly, the development of the 
digital economy has a positive impact on economic growth and the ability of economic agents to meet their needs. Let us consider the risks associated with the introduction of digital technologies.

Cybercrime. The main risk associated with the introduction of digital technologies is the growing risk of cybercrime. Large-scale application of digital technologies in various spheres of activity as a result leads to accumulation of risks in the conditions of activity of the interconnected complex systems. The danger lies in the possible destruction of information infrastructure, data theft and fraud. The activities of cybercriminals are transnational in nature and it is difficult to calculate the identity of a criminal when using modern technologies. The object of attack is information, an important resource in post-industrial society. Destroying, stealing and access to information can lead to very negative consequences.

Digital public administration:

1. Risks:

1.1. Cybercrime

1.2. Dependence on the Internet

1.3. Threat of job cuts in the labor market;

1.4. The educational system lagging behind the digital economy

1.5. Digital Inequality

1.6. The concentration of digital technology in individual players, due to non-competitive struggle;

1.7. Reduced ability of state control;

1.8. Leaving the regulatory framework behind technological development

2. Opportunities

2.1. Efficiency of the labor market;

2.2. Development of safety technology;

2.3. Reduction of transactional costs;

2.4. Availability and improvement of the quality of social services provided to the population

2.5. Use of innovative methods of policy formation and impact assessment.

Dependent on the Internet. Excessive dependence of economic entities on the Internet. The risk lies in the possibility of disturbance of the normal functioning of the information infrastructure, which completely paralyses the work of various systems at all levels. The population is psychologically dependent on the network, there is a phenomenon of "clip thinking", the complexity of perception of large amounts of information.

The threat of job cuts on the labour market. Digitalization involves the development of robotics, which in turn leads to job losses and the disappearance of a number of professions with particularly low and medium skill levels. Lagging education system. The education system has not had time to respond to the changes brought about by digitalization. It is necessary to adapt educational programs to modern transformations of the labor market, a flexible system of personnel, the possibility of additional education during working life.
Digital inequality can manifest itself at the micro level between citizens, taking into account their age, gender and educational characteristics.

The concentration of digital technologies among individual players, due to non-competitive struggle. In the information market, oligopolization processes are possible, where the concentration of factors of production in the hands of a small number of owners.

Reduction of state control. formation of horizontal connections bypassing traditional ways of exchange and consumption of goods and services is possible in the information society. The state needs to stop these facts, but at the same time not to create difficulties for law-abiding citizens and entrepreneurs.

Leaving the legal and regulatory framework behind the development of technology. There is a discrepancy between the legal interpretation and actual economic crimes using information and communication networks.

Let us determine the favourable opportunities for the introduction of digital technologies.

Efficiency of the labour market. Digitalization provides opportunities for the emergence of new professions. There are opportunities for remote work. Network structures are being created, the need to rent offices is decreasing, which leads to savings for companies.

Development of security technologies. The development of digital identity technologies and blockbusters, the implementation of which will solve two key problems: the preservation of change history and guarantee of the authenticity of the data entered, as well as the identity of all participants in the decentralized platform, makes it possible to ensure the security of economic entities, reducing transaction costs. The use of modern technologies (drones, robots, artificial intelligence systems) reduces the need for human participation in hazardous activities, reduces the risk of "human factor".

Reducing transaction costs by reducing the role of intermediaries through the creation of digital services. Direct contact between supplier and buyer of goods and services takes place.

Availability and quality of social services to the public are improved. Creation in Russia of effective and convenient electronic services that simplify interaction between the state and citizens and entrepreneurs in various areas.

Use of innovative methods of policy formation and assessment of its impact. Digital technologies provide an opportunity for active participation of citizens in the evaluation of government actions through feedback.

As a result of the transition to a new technological mode and the use of digital technologies, Russia has a unique chance to achieve competitiveness at the international level, improve the quality of life of the population, and solve many problems. Transition is impossible without certain risks. There is a need for a qualitative analysis and study of such risks to minimize them [20].

Thus, public administration is faced with the important task of not blocking the introduction of new technologies and at the same time reducing the risks associated with the development of digital trends. 


\section{ACKNOWLEDGMENT}

Digital technology offers great opportunities for transforming public administration. In the digital transformation phase, digital technologies are integrated into policymaking, creating opportunities for the implementation of various public policy options that cannot be implemented without the use of technology. Returning to our hypothesis "Are the risks assumed by the state justified in building a "digital state", we should agree that if the risks are properly identified, it is possible to minimize the negative consequences of the introduction of digital technologies. Thus, by minimizing the risks we will achieve a high return of opportunities from digitalization.

\section{CONCLUSION}

Today, the digital economy serves as an effective basis for the development of public administration, economy, Business, social sphere and the whole society. Having considered the opinions of various authors of the concept. Digital economy is a new way of life, in which there is an active development of the economy, business management, social sphere under the influence of modern information and communication technologies. The article showed the basic principles and elements of creating digital government. It shows the changes that have taken place in the management of socio-economic systems and the life of society under the influence of the active use of digital technologies and the implementation of programs and strategies for the development of information society in the Russian Federation. The main risks and new opportunities for creating a digital government have been identified

On the basis of the studied information, we propose a schematic specification of the main transformations taking place in the management of socio-economic systems in the period of digital dominance.

Digital technology has firmly entered our daily lives. Modern scientific and technological processes become unfeasible without introducing and using modern approaches and technologies. Digital technologies make it possible to realize a huge number of diverse scientific, technical and technological tasks in minimal time intervals [8].

In the epoch of universal digitalization, one of the priorities is to increase the efficiency of public administration, interaction of society and enterprises with public authorities, improving the quality of public services through the active introduction of digital technologies in public systems.

Rapid development of digital technologies and their introduction into all social and economic spheres of life requires from the state, enterprises and citizens rapid and qualitative mastering of innovations and their application in practice.
This work was supported by National Natural Science Foundation of China (61303022), Natural Science Major Project of Jiangsu Higher Education Institutions (17KJA520002), and Nanjing Scientific \& Technological Innovation Project for Outstanding Overseas Returnees.

\section{REFERENCES}

[1] A. Aptekman, V. Kalabin, V. Klintsov, E. Kuznetsova, V. Kulagin, I. Yasenovets Digital Russia: New Reality. 2017.6

[2] Vladimir Mesropyan First Deputy Head of the Project Office for Digital Economy of the Russian Federation Moscow, 2018

[3] Digital economy regulation issues. Analytical report of the Foundation "Center for Strategic.

[4] World Bank. 2016. World Development Report 2016: Digital Dividends by The World Bank. 2016. World Development Report 2016 Digital dividends. URL:

https://openknowledge.worldbank.org/bitstream/handle/ 10986/23347/210 (accessed 08.01.2018).

[5] Yuri Gribanov. Digital transformation of social and economic systems on the basis of development of service integration institute // Humanitarian and legal research. 2018. №4. CyberLeninka - scientific electronic library [Electron resource]. Access mode: http://www.rsl.ru (date of address: 02.04.2020).

[6] Dobrolyubova, E.I. Digital future of the state administration by results / E.I. Dobrolyubova, V.N. Yuzhakov, A.A. Efremov, E.N. Klochkova, E.V. Talapina, Yu. - Moscow: Publishing House "Delo" RANHIGS, 2019. - - 114c. - (Scientific papers: public administration).

[7] Report "On the results of the Ministry of Economic Development of Russia for 2017 and tasks for 2018". Ministry of Economic Development of the Russian Federation. M., 2018.

[8] Russian Information Agency TASS" https://tass.ru/ekonomika/4389411 (date of address 28.02.2020).

[9] Kapranova Ludmila Dmitrievna Digital economy in Russia: state and prospects of development // Ekonomika. Taxes. Law. 2018. №2. CyberLeninka - 
electronic library [Electron resource]. Access mode: http://www.rsl.ru (date of address: 09.04.2020).

[18] Kholodnaya Elena Viktorovna On some perspectives of development of electronic public administration in conditions of digital transformation (in Russian) // Humanitarian and legal research. 2018. №4. URL: https://cyberleninka.ru/article/n/onekotoryh-perspektivah-razvitiya-elektronnogogosudarstvennogo-upravleniya-v-usloviyah-tsifrovoytransformatsii (date of address: 09.04.2020).

[19] Shaulova, T.V. Digitalization and efficiency of the state administration // Proceedings of the North-West Institute of Management RANKHIGS. Moscow Tom: 10 №: 2 (39). 2019 Pp. 243-252

[20] Eskindarov MA Maslennikov V., Maslennikov O. V. Risks and Chances of Digital Economy in Russia. Finance: Theory and Practice. 2019 ;23(5)

[21] "Vedomosti [Electronic Resource] www.vedomosti.ru.
[13] Smotritskaya, I.I.; Chernykh, S.I. Modern tendencies of the state administration digital transformation (in Russian) // Bulletin of the Institute of Economics of RAS. 2018. №5. // CyberLeninka scientific electronic library [Electron resource]. Access mode: http://www.rsl.ru. (Date of address: 28.03.2020).

[14] Smotritskaya Irina Ivanovna Public administration in conditions of development of digital economy: strategic challenges and risks (in Russian) // ETAP. 2018. № 4. // CyberLeninka - scientific electronic library [Electron resource]. Access mode: http://www.rsl.ru. Date of address: 28.03.2020

[15] Solozhentsev, E.D. Digital economy management (in Russian) // Actual problems of economy and management. Saint-Petersburg State University of Aerospace Instrumentation 2018. №1. p 136-153.

[16] Strategy for the development of information society in the Russian Federation for 2017-2030 (approved by Presidential Decree of 09.05.2017 № 203 // SPS "Garant" [Electronic resource]. URL: https://www.garant.ru/products/ipo/prime/doc/7157057 0/\#1000 (date of address: 09.04.20).

[17] Tikhomirov Boris Ivanovich Digitalization of social and economic development: a thorny way to a new quality of information society // Ekonomika. Taxes. Law. 2019. №4. CyberLeninka - scientific 